\title{
Some Sensory Neurons Express Neuropeptide Y Receptors: Potential Paracrine Inhibition of Primary Afferent Nociceptors Following Peripheral Nerve Injury
}

\author{
Patrick W. Mantyh, ${ }^{1,2}$ Clark J. Allen, ${ }^{1,2}$ Scott Rogers, ${ }^{1,2}$ Eric DeMaster, ${ }^{1,2}$ Joseph R. Ghilardi, ${ }^{1,2}$ Tony Mosconi, ${ }^{3}$ \\ Lawrence Kruger, ${ }^{3}$ Peter J. Mannon, ${ }^{4}$ Ian L. Taylor, ${ }^{4}$ and Steven R. Vigna ${ }^{4}$ \\ 1 Molecular Neurobiology Laboratory, Veterans Administration Medical Center, Minneapolis, Minnesota 55417, ${ }^{2}$ Department \\ of Psychiatry, University of Minnesota, Minneapolis, Minnesota 55455, ${ }^{3}$ Department of Anatomy and Cell Biology and the \\ Brain Research Institute, UCLA, Los Angeles, California 90024, and ${ }^{4}$ Departments of Cell Biology and Medicine, Duke \\ University Medical Center, Durham, North Carolina 27710
}

\begin{abstract}
Neuropeptide Y (NPY) has been suggested to exert antinociceptive actions by inhibiting the release of neurotransmitters from trigeminal and dorsal root ganglia (DRG) neurons, but the site of direct NPY action in vivo and the NPY receptor subtype mediating these effects are unknown. ${ }^{125}$ I-peptide YY (PYY) was used to localize and characterize NPY receptor binding sites in trigeminal ganglia, DRG, and spinal cord of the rat, rabbit, and monkey. In the rat, rabbit, and monkey, 5-20\% of trigeminal ganglia and DRG neurons express NPY binding sites. Unilateral cuff-induced neuropathy or transection of the rat sciatic nerve did not significantly alter the density or number of DRG neurons expressing NPY receptors. A unimodal size distribution for L4 and L5 DRG neurons expressing NPY binding sites in the rat was determined, with a mean cross-sectional area of $947 \mu \mathrm{m}^{2}$. In the spinal cord the highest concentration of NPY receptors is found in laminae I, II, $\mathbf{V}, \mathbf{X}$, and Onuf's nucleus. Pharmacological experiments using selective $Y 1$ and $Y 2$ receptor antagonists suggest that $Y 2$ is the prominent NPY receptor subtype expressed in trigeminal ganglia neurons, DRG neurons, and spinal cord. Previous studies have demonstrated that a population of large-diameter, presumably myelinated primary afferents express NPY after peripheral nerve injury. NPY released from these injured large-diameter DRG neurons may act in a paracrine fashion to block the transmission of nociceptive information from the small- and medium-diameter DRG neurons that constitutively express NPY receptors. NPY receptors are therefore uniquely positioned to inhibit primary afferent nociceptors directly, especially after peripheral nerve injury.

[Key words: dorsal root ganglion, sensory neurons, neuropeptide $Y$, nociceptor, neuropeptide $Y$ receptors, peripheral nerves, trigeminal ganglion]
\end{abstract}

Neurons with cell bodies located in a trigeminal ganglion or dorsal root ganglion (DRG) convey somatic sensory information from peripheral tissues to the CNS. These pseudounipolar sen-

Received Sept. 24, 1993; revised Dec. 13, 1993; accepted Dec. 31, 1993.

This work was supported by a VA Merit Review (P.W:M.), NIH Grants NS23970 (P.W.M.), DK-44072 (I.L.T.), NS-5685 (L.K.), and NRSA Fellowship NS09176 (T.M.)

Correspondence should be addressed to Dr. Patrick W. Mantyh, Molecular Neurobiology Lab (151), VA Medical Center, Minneapolis, MN 55417.

Copyright (C) 1994 Society for Neuroscience $0270-6474 / 94 / 143958-11 \$ 05.00 / 0$ sory neurons are unique in that they span the blood-brain barrier, having one process that terminates in the spinal cord and another terminating in the peripheral tissue. Modulation of sensory input into the CNS is a universal feature of mammalian sensory systems (Kandel et al., 1991). In the somatosensory system, the first level where this modulation could occur is at the sensory neuron itself, that is, presynaptic modulation of the trigeminal ganglion or DRG neuron.

Recent work has suggested that in addition to their afferent functions, DRG neurons also play an efferent role in regulating the tissues they innervate. DRG neurons have been implicated in regulating blood flow, gastric motility, inflammation, plasma extravasation, and the response to tissue injury (Lembeck and Holzer, 1979; Mantyh et al., 1988; Kruger et al., 1989; Barnes et al., 1990). One mechanism by which this efferent regulation can occur is via antidromic activation of sensory terminals with the resulting release of neurotransmitters from the peripheral terminals of DRG neurons (Lam and Ferrell, 1991; Santicioli et al., 1993). An example of this is the release of substance $\mathbf{P}$ from the primary afferent terminal after tissue injury. This release of substance $P$ in the innervated tissue results in vasodilatation and plasma extravasation, both of which are components of the phenomenon known as neurogenic inflammation (Louis et al., 1989; Barnes et al., 1990; Lötvall et al., 1990; PedersenBjergaard et al., 1991; Lei et al., 1992). What has also become clear is that the innervated tissue can exert effects on the primary afferent neuron by the release of ligands that bind to receptors expressed by the sensory nerve terminals. An example of this is the release of opioid peptides from immunocytes. Peripherally released opioids interact with opiate receptors on sensory neurons and might thereby inhibit the transmission of nociceptive input by the DRG neurons that normally occurs after tissue injury (Levine and Taiwo, 1989; Stein et al., 1990a,b).

Neuropeptide Y (NPY) is a 36 amino acid peptide that belongs to the pancreatic polypeptide (PP) family of structurally related peptides. The PP family consists of PP, NPY, and peptide YY (PYY), all of which share a common secondary structure containing a $\beta$ fold (the "PP fold") (Fuhlendorff et al., 1990; Jorgensen et al., 1990). Immunochemical studies have shown that NPY is synthesized by neurons in the spinal cord and by postganglionic sympathetic and parasympathetic neurons, and thus is widely distributed in both the CNS and in peripheral tissues (Lacroix et al., 1990; Lundberg et al., 1990; Schalling et al., 1991). Recently it has been reported that NPY is present in 
a population of DRG neurons, but only after peripheral nerve injury (Wakisaka et al., 1991, 1992; Noguchi et al., 1993). Previous in vitro studies have suggested that NPY receptors are expressed by cultured DRG neurons obtained from neonatal rats (Ewald et al., 1988; Bleakman et al., 1991), and in vivo studies have demonstrated that NPY can potently inhibit the release of several neurotransmitters from sensory neurons (Giuliani et al., 1989; Duggan et al., 1991; Hua et al., 1991). Together these results suggest that NPY may play a role in regulating the transmission of nociccptive input by trigeminal and dorsal root ganglion neurons, particularly after peripheral nerve injury.

The present studies were designed to (1) determine whether trigeminal ganglia neurons, DRG neurons, and/or their supporting cells express NPY receptor binding sites, (2) define the percentage and diameters of the trigeminal ganglia and DRG neurons expressing NPY receptors, (3) determine the pharmacological profile of these receptors, (4) determine if there are substantial species differences in the expression of these receptors, and (5) compare expression of NPY receptors in normal rats and in rats with a painful mononeuropathy and with peripheral nerve transection.

\section{Materials and Methods}

\section{Radioligand preparation}

PYY was used instead of NPY as the radioligand because PYY binding resulted in higher specific:nonspecific binding ratios and because PYY has been demonstrated to bind to the same population of receptors as NPY (Sheikh et al., 1989). Porcine PYY (pPYY) was iodinated by mixing $5 \mu \mathrm{g}$ of pPYY, $5 \mu \mathrm{l}$ of $\mathrm{Na}^{125} \mathrm{I}(500 \mu \mathrm{Ci}), 600 \mathrm{ng}$ of lactoperoxidase, and $10 \mu \mathrm{l}$ of $0.006 \%$ hydrogen peroxide in $85 \mu \mathrm{l}$ of $200 \mathrm{~mm}$ sodium phosphate buffer, $\mathrm{pH}$ 7.4. After incubation for $5 \mathrm{~min}$ at room temperature, an additional $10 \mu \mathrm{l}$ of $0.006 \%$ hydrogen peroxide was added and the reaction was terminated after incubation for an additional 5 min by addition of $95 \mu 1$ of $50 \%$ acctic acid. The reaction mixture was fractionated by reversed-phase high-performance liquid chromatography to a specific activity of approximately $2000 \mathrm{Ci} / \mathrm{mmol}$. The second major peak of radioactivity corresponding to ${ }^{125} \mathrm{I}-\mathrm{Tyr}^{36}$-monoiodoPYY was used for all binding studies (Sheikh et al., 1989). After purification, ${ }^{125} \mathrm{I}-\mathrm{PYY}$ was stored at $-20^{\circ} \mathrm{C}$ in a solution containing $1 \% \mathrm{BSA}$. This radioligand stock solution was diluted to a working concentration of 100 pM shortly before incubation with either membranes or tissue sections.

\section{Homogenate receptor binding}

New Zealand White rabbits $(5-7 \mathrm{lb})$ were anesthetized with intramuscular pentobarbital followed by intravenous ketamine, and the spinal cord and dorsal root ganglia were rapidly removed. These were then flash frozen and stored at $-70^{\circ} \mathrm{C}$ until used. At the time of the binding the tissue was thawed and homogenized with a polytron (Brinkmann Instruments, NY) in $10 \mathrm{ml}$ of an ice-cold buffer that contained (in mM) $137 \mathrm{NaCl}, 2.68 \mathrm{KCl}, 2.05 \mathrm{MgCl}_{2}, 1.8 \mathrm{CaCl}_{2}, 0.1 \% \mathrm{mg} / \mathrm{ml}$ glucose, 4 $\mathrm{mg} /$ liter leupeptin, $2 \mathrm{mg} /$ liter chymostatin, and $20 \mathrm{HEPES}, \mathrm{pH} 7.4$ (Gimpl et al., 1990). The homogenate was then centrifuged at 14,000 $\times g$ at $4^{\circ} \mathrm{C}$ for 15 min (SS-34 rotor, Sorvall RC5C, Sorvall Instruments, Danbury, CT). The resulting pellet was washed and resuspended in a final volume of $4.5 \mathrm{ml}$ of the same buffer.

For binding studies, $400-600 \mu \mathrm{g} / \mathrm{ml}$ of tissue membrane protein was incubated with $100 \mathrm{pm}^{125} \mathrm{I}-\mathrm{PYY}$ in $200 \mu \mathrm{l}$ of buffer A containing $0.5 \%$ bovine serum albumin and $0.025 \%$ bacitracin. Membrane-bound ${ }^{125} \mathrm{I}-$ PYY was separated from free ${ }^{125}$ I-PYY by centrifugation at $12,000 \times$ $g$ for $15 \mathrm{~min}$ (5413 Eppendorf microcentrifuge). The total amount of radioactivity added to each tube and the amount of radioactivity bound to the tissue membranes were measured on a Packard gamma counter. Nonsaturable binding was defined as the amount of membrane-associated radioactivity when $1 \mu \mathrm{M}$ nonradioactive PYY was added to the incubation mixture. For studies of competitive inhihition of hinding, increasing amounts of unlabeled peptides $\left(10^{-11}\right.$ to $\left.10^{-6} \mathrm{M}\right)$ were added to the incubation mixture.

\section{Autoradiographic localization}

Tissue preparation. Eight adult male New 7ealand White rabbits (Birchwood Valley Farm, Red Wing, MN), 15 male adult Sprague-Dawley rats (250 gm; Holtzman, Madison, WI), and three adult Macaca nemestrina monkeys (Wisconsin Regional Primate Research Center, Madison, WI) were overdosed with Nembutal and perfused transcardially with phosphate-buffered saline $\left(\mathrm{pH} \mathrm{7.4)}\right.$ at $4^{\circ} \mathrm{C}$. The animals were placed on ice and the dorsal root ganglia, Irigeminal ganglia, and spinal cords were rapidly dissected out. The tissue was then frozen on dry ice in Tissue-Tek O.C.T. Compound (Miles, Elkhart, IN), serially sectioned at $15 \mu \mathrm{m}$, thaw-mounted on gelatin-coated slides, and stored for up to 3 months at $-70^{\circ} \mathrm{C}$.

Sciatic nerve injury was produced in 22 male Sprague-Dawley rats (180 gm; Charles River, Boston, MA). Under Nembutal anesthesia (35 $\mathrm{mg} / \mathrm{kg}$, i.p.), the right sciatic nerve was exposed in midthigh proximal to the trifurcation and freed from connective tissue by sharp dissection. Sixteen animals received an experimental cuff neuropathy produced by applying four nonconstrictive $0.5 \mathrm{~mm}$ segments of polyethylene tubing (inner diameter -0.030 inches; Clay Adams) to enclose the sciatic nerve. Six additional animals received complete sciatic nerve transection. Proximal stumps were tightly ligated, and a 1-2 $\mathrm{mm}$ segment of nerve was removed to prevent regeneration. Neuropathic and axotomized rats were killed on $7 \mathrm{~d}(N=2$ neuropathic, 1 axotomized), $14 \mathrm{~d}(N=12$, $4)$, or $28 \mathrm{~d}(N=2,1)$ postsurgery and both the ipsilateral and contralateral L4, L5, and L6 ganglia were dissected out on ice, frozen on dry ice in Tissue-Tek O.C.T. Compound (Miles, Elkart, IN), and processed for quantitative autoradiography.

Cuff neuropathy produced behavioral alterations similar to those reported in rat and human painful neuropathies, including hyperalgesia and allodynia (Bennett and Xie, 1988). Quantitative analysis of alterations in axon fiber spectrum revealed a progressive decrease in the number of large myelinated axons with a maximum deficit apparent at $14 \mathrm{~d}$ postsurgery $(77 \%$ below the untreated contralateral nerve) (Mosconi and Kruger, 1992). By $28 \mathrm{~d}$, many axons with extremely thin myelin sheathes are evident, presumably reflecting regeneration and/or remyelination, and coinciding with behavioral evidence of functional recovery. In contrast, operated limbs of the transected animals were flaccid and anesthetic and showed no signs of functional recovery by $28 \mathrm{~d}$ postsurgery.

Receptor binding protocol. The slide-mounted tissue sections were brought to room temperature and preincubated in a Krebs-Ringer buffer (118 m MaCl, $1.2 \mathrm{~mm} \mathrm{MgSO}_{4} \cdot 7 \mathrm{H}_{2} \mathrm{O}, 1.2 \mathrm{~mm} \mathrm{KH}_{2} \mathrm{PO}_{4}, 5.6 \mathrm{~mm}$ glucose, $\left.4.7 \mathrm{mM} \mathrm{KCl}, 2.5 \mathrm{mM} \mathrm{CaCl}_{2}\right)$, pH 7.4, for $1 \mathrm{hr}$ prior to incubation with the radioligand (Allen et al., 1993). The sections were then incubated at $22^{\circ} \mathrm{C}$ for $2 \mathrm{hr}$ in a solution of $100 \mathrm{pM}{ }^{125} \mathrm{I}-\mathrm{PYY}$ in Krebs-Ringer buffer, $\mathrm{pH} 7.4$, containing $0.1 \%$ bovine serum albumin (BSA) and $0.05 \%$ bacitracin. To estimate nonsaturable binding, paired serial sections were incubated as described except that $1 \mu \mathrm{M}$ nonradioactive PYY or NPY was present in the incubation medium. In all experiments the unlabeled peptides were obtained from Bachem (Torrance, CA). After incubation, the slides were washed four times in incubation buffer, $\mathrm{pH} 7.4\left(4^{\circ} \mathrm{C}, 4\right.$ min each), rinsed once in distilled water $\left(4^{\circ} \mathrm{C}, 5 \mathrm{sec}\right)$, and then quickly dried in the cold room under a stream of cold air. After $3 \mathrm{hr}$ of further drying at $4^{\circ} \mathrm{C}$, sections were stored over desiccant at room temperature overnight before being apposed to $\mathrm{x}$-ray film or dipped in nuclear emulsion.

Pharmacological characterization of the NPY binding sites. The specificity of the ${ }^{125} \mathrm{I}-\mathrm{PYY}$ binding sites was characterized by performing the binding as described above except that nonradioactive NPY, PYY, PP, Leu ${ }^{31}$, Pro $^{34}-\mathrm{NPY}$ (a selective Y1 receptor agonist), or $\mathrm{NPY}_{13-36}$ (a selective $Y 2$ receptor agonist) was added to the incubation medium in various concentrations. The slides were then processed for autoradiography and the density of the Hyperfilm silver grains was analyzed by image analysis as described below.

Autoradiography. The slide-mounted tissue sections were placed in apposition to $\beta$-max Hyperfilm (Amersham) alongside iodinated standards (Amersham). After 1-3 weeks the film was developed in D-19 developer, fixed, and washed. When a higher degree of histological resolution was required, the tissue was processed for standard emulsiondipped autoradiography. The emulsion-dipped autoradiograms were developed, stained with Nissl or thionin, and mounted with Permount. Dark-field and bright-field photomicrographs were then taken of the silver grains and counterstained sections, respectively. This approach generated three complementary images: the Hyperfilm autoradiograms, 

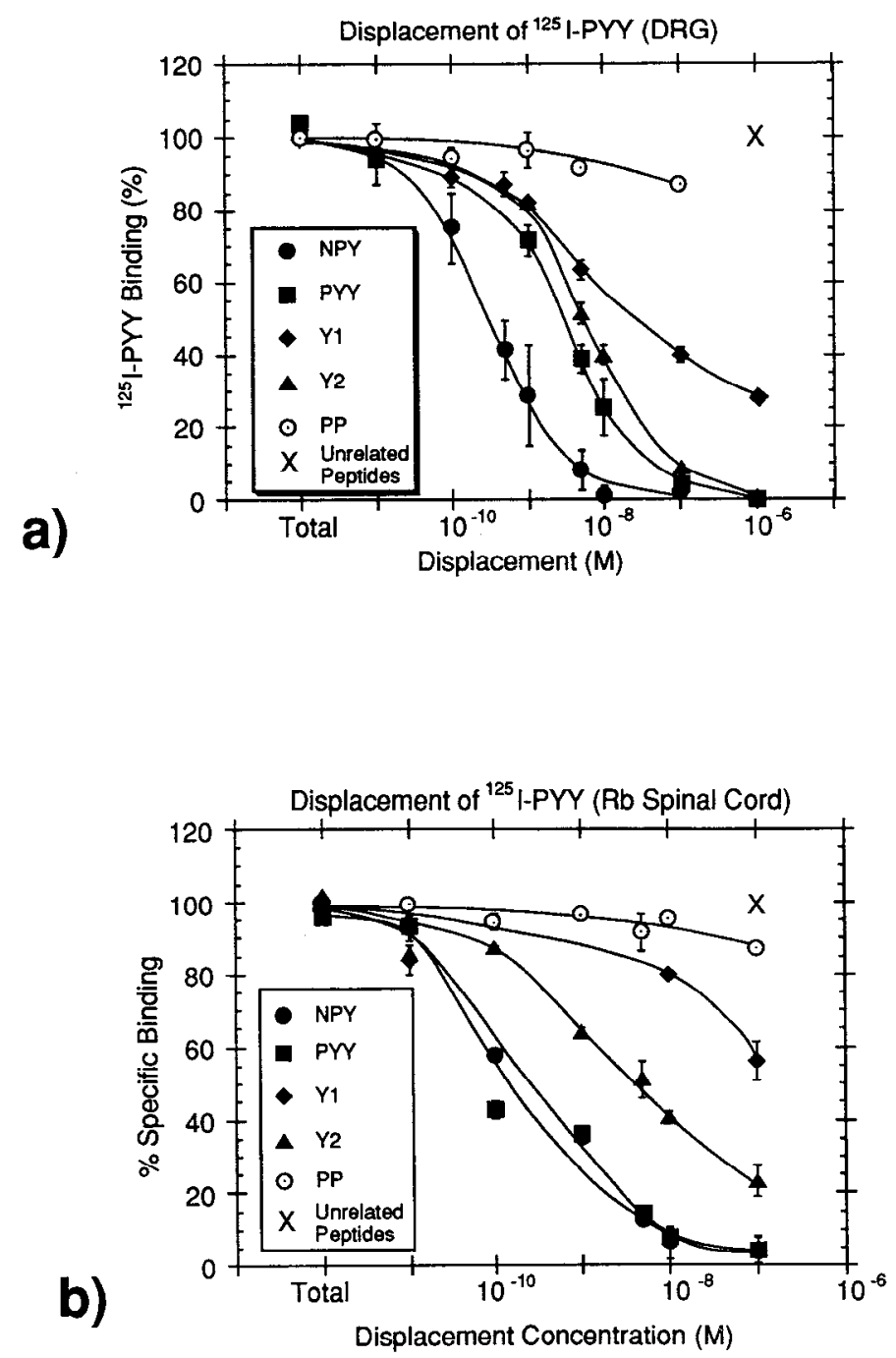

Figure 1. Pharmacological displacement of ${ }^{125} \mathrm{I}-\mathrm{PYY}$ binding in membranes of rabbit DRG and rabbit spinal cord. Rabbit DRG (a) or spinal cord $(b)$ from all spinal levels was pooled and homogenized as described. Note that in both the spinal cord and DRG the prominent receptor subtype appears to correspond to the $\mathrm{Y} 2$ subtype, as the $\mathrm{Y} 2$ agonist (NPY ${ }_{13-36}$ ) appears to be significantly more potent than the $Y 1$ agonist $\left(\right.$ Leu $^{31}$, Pro $^{34}-$ NPY $)$ in displacing ${ }^{125}$ I-PYY from these tissues. The unrelated peptides $(X)$ that failed to show any displacement of ${ }^{25}$ I-PYY included cholecystokinin, neurokinin A, neurokinin B, and substance $P$.

which were analyzed for quantitative densitometry; the emulsion-dipped slides, which provided detailed histological resolution of the developed silver grains; and the counterstained sections, which allowed identification of the cell type expressing the saturable binding site.

Image analysis. To estimate quantitatively the density of radiolabeled neuropeptide binding sites and to generate inhibition curves from the autoradiographic displacement experiments, microdensitometry was performed on a Macintosh-based system using the NIH IMAGE program, version 1.37 .

\section{Results}

Homogenate binding analysis of ${ }^{125} I-P Y Y$ binding to membranes of the rabbit $D R G$ and spinal cord

Membrane preparations from rabbit DRG or spinal cord were used to characterize the ${ }^{125}$ I-PYY binding sites in these tissues (Fig. 1). In rabbit DRGs the rank order of displacement of ${ }^{125} \mathrm{I}_{-}$ PYY was NPY $>$ PYY $>\mathrm{NPY}_{13-36}>\mathrm{Leu}^{31}, \mathrm{Pro}^{34}$-NPY $>$ PP (Fig. 1a). Scatchard analysis revealed a one-site best fit with a
$K_{d}$ of $3.6 \mathrm{~nm}$ and a $B_{\max }$ of $352.4 \mathrm{fmol} / \mathrm{mg}$ protein. In rabbit spinal cord, a similar pharmacological profile was obtained with the rank order of displacement of ${ }^{125}$ I-PYY being NPY $>$ PYY $>\mathrm{NPY}_{13-36}>\mathrm{Leu}_{31}, \mathrm{Pro}_{34}-\mathrm{NPY}>\mathrm{PP}$ (Fig. 1b). Scatchard analysis revealed a one-site best fit with a $K_{d}$ of $1 \mathrm{~nm}$ and a $B_{\max }$ of $489.7 \mathrm{fmol} / \mathrm{mg}$ protein.

\section{Autoradiographic analysis of ${ }^{125} I-P Y Y$ binding sites in the rabbit $D R G$, trigeminal ganglion, and spinal cord}

Several dozen rabbit DRG and trigeminal ganglia were examined for ${ }^{125}$ I-PYY binding sites. In general, nearly all the specific binding sites were observed over neurons with few specific binding sites overlying the supporting cells (Fig. 2). Dorsal root ganglion neurons with a silver grain density greater than fourfold higher than background lcvels were considered to be labeled. The ${ }^{125} \mathrm{I}-\mathrm{PYY}$ ligand binds to $5.2 \pm 2.9 \%(N=4016), 10.2 \pm$ $3.9 \%(N=2907), 6.3 \pm 3.9 \%(N=3060), 9.5 \pm 2.6 \%(N=$ $5067)$, and $15.1 \pm 3.3 \%(N=3848)$ of the neurons in the cervical, thoracic, lumbar, sacral, and trigeminal ganglia, respectively. The numbers in parentheses indicate the total number of neurons examined. The specificity of the ${ }^{125}$ I-PYY ligand is demonstrated by the highly localized silver grains overlying individual neurons, while only background levels of silver grains are found over the surrounding supporting cells and intercellular space (Fig. 2).

In the spinal cord, the highest density of specific ${ }^{125}$ I-PYY binding sites is present in laminae I, II, V, X, and Onuf's nucleus. Low but detectable levels of specific ${ }^{125}$ I-PYY binding sites were present in laminae III-IX.

Comparisons of the inhibition of ${ }^{125} \mathrm{I}-\mathrm{PYY}$ binding by $\mathrm{Y} 1$ $\left(\mathrm{Leu}^{31}, \mathrm{Pro}^{34}-\mathrm{NPY}\right)$ and a $\mathrm{Y} 2\left(\mathrm{NPY}_{13-36}\right)$ receptor agonist in a displacement series demonstrated that the $\mathrm{Y} 2$ agonist was significantly more potent than the $\mathrm{Y} 1$ agonist in displacing ${ }^{225}[-$ PYY from the DRG, trigeminal ganglia, and spinal cord tissue sections, suggesting that the receptor binding sites in these tissues are of the $\mathrm{Y} 2$ subtype.

\section{Autoradiographic analysis of ${ }^{125} I-P Y Y$ binding sites in the rat} $D R G$, trigeminal ganglion, and spinal cord

Several hundred rat DRG and several dozen trigeminal ganglia were examined for ${ }^{125}$ I-PYY binding sites. Nearly all the specific binding sites were observed over neurons with few if any specific binding sites overlying the supporting cells (Fig. 3). In the DRG and trigeminal ganglion of the rat, several thousand neurons were examined for ${ }^{125} \mathrm{I}-\mathrm{PYY}$ labeling. In the rat, specific ${ }^{125} \mathrm{I}-$ PYY binding sites were observed overlying $12.8 \pm 3.8 \%(N=$ $1607), 12.2 \pm 5.4 \%(N=1687), 13.1 \pm 5.2 \%(N=1856), 11.7$ $\pm 7.5 \%(N=1655)$, and $16.8 \pm 4.4 \%(N=2152)$ of the neurons in the cervical, thoracic, lumbar, sacral, and trigeminal ganglia, respectively. The frequency distribution of the cross-sectional area of L4 and L5 DRG neurons expressing NPY receptors was also calculated (Fig. 4). Neurons expressing NPY receptors were mainly small to medium sized, with a cross-sectional area of $947 \pm 485 \mu \mathrm{m}^{2}$. At 7,14 , or $28 \mathrm{~d}$ after cuff-induced sciatic neuropathy or sciatic nerve transection there is relatively little change in either the number of DRG neurons expressing NPY receptors or the density of NPY receptors expressed per neuron (Fig. 3, Table 1).

In the rat spinal cord at the cervical, thoracic, lumbar, and sacral levels, the highest densities of saturable ${ }^{125}$ I-PYY binding sites were found in laminae I, II, V, X, and Onuf's nucleus. A lower but still detectable level of saturable PYY binding sites 

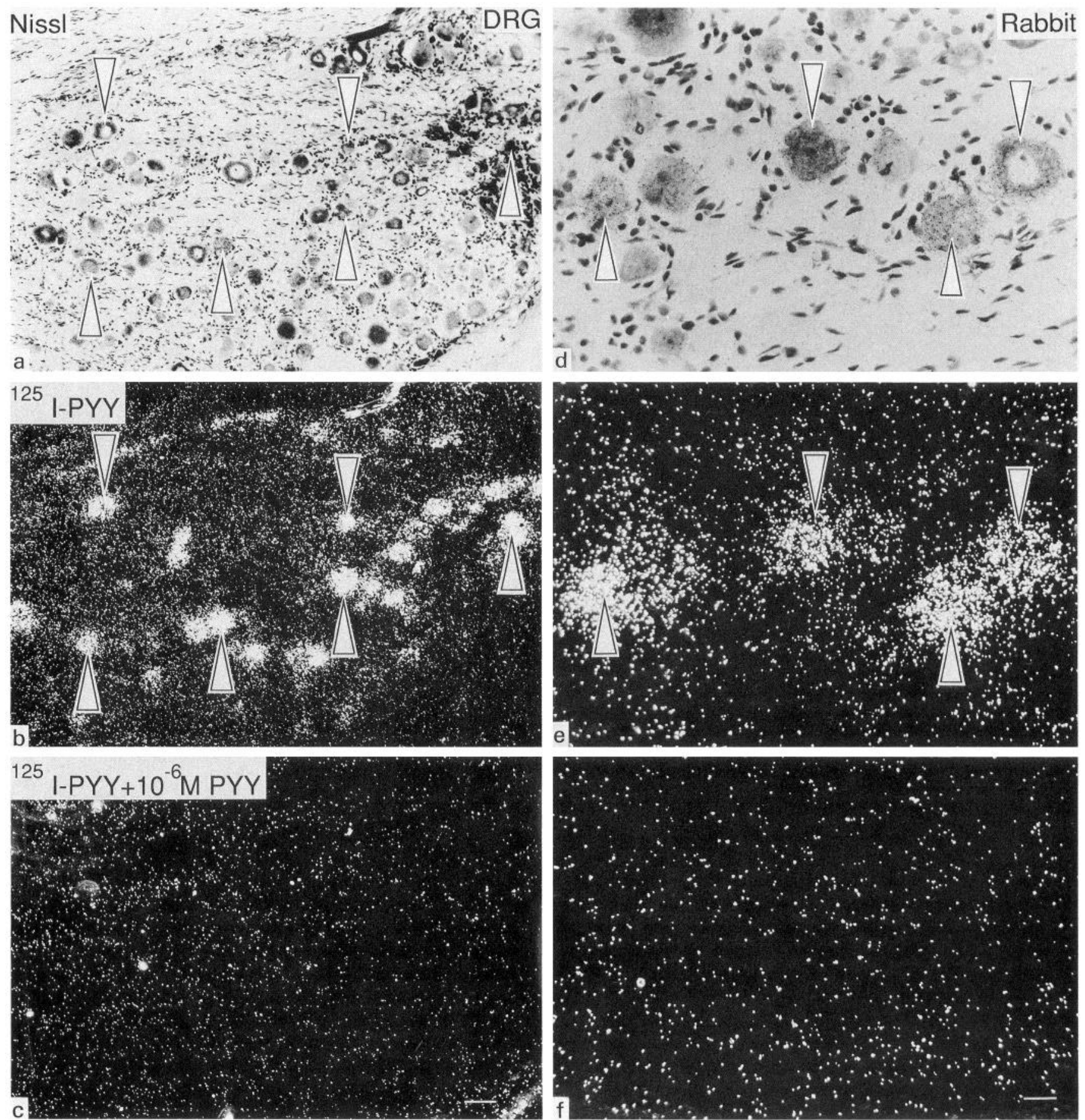

Figure 2. Autoradiographic localization of ${ }^{125} \mathrm{I}-\mathrm{PYY}$ receptor binding sites in rabbit DRG neurons. $a$ and $d$, Light-field photomicrographs of rabbit DRG (C5) neurons that have been Nissl stained to visualize the individual neurons within the ganglion. $b$ and $e$, Dark-field photomicrograph of the same section shown in $a$ and $d$, respectively, which has been dipped in nuclear emulsion to show individual neurons expressing the ${ }^{125}$ I-PYY binding sites, which appear as white silver grains. $c$ and $f$, Dark-field photomicrograph of sections serially adjacent to $b$ and $e$, respectively, showing the nonspecific binding. The arrowheads point to individual DRG neurons that contain PYY receptors. Note that the silver grains are localized primarily over the neurons, with few specific binding sites present over the intercellular space or glial cells. Scale bars: $60 \mu \mathrm{m}$ for $a-c, 23 \mu \mathrm{m}$ for $d-f$.

was observed in laminae III-IX. Characterization of the ${ }^{125} \mathrm{I}-$ PYY receptor binding sites in sections of the rat DRG, trigeminal ganglia, and spinal cord suggests that the predominant NPY receptor subtype expressed by these cells is the Y2 subtype. For the NPY receptor expressed by DRG and trigeminal ganglia neurons, as well as in the spinal cord, the rank order of potency for displacing ${ }^{125} \mathrm{I}-\mathrm{PYY}$ from the tissue sections was PYY = NPY > PP. In another displacement series, NPY ${ }_{13-36}$ (Y2 agonist) appeared to be significantly more potent than $\mathrm{Leu}^{31}, \mathrm{Pro}^{34}$ NPY (Y1 agonist) at displacing ${ }^{125}$ I-PYY from the DRG, trigeminal ganglia, and spinal cord, suggesting that the receptor binding sites on these neurons are of the Y2 subtype. Thus, at 
Figure 3. Autoradiographic localization of ${ }^{125}$ I-PYY receptor binding sites in the normal, ligated, and transected rat DRG. Dark-field photomicrographs show the localization of ${ }^{125}$ I-PYY binding sites in the normal $(b)$, ligated $(7 \mathrm{~d}$; $d)$, and transected $(7 \mathrm{~d} ; e, f)$ rat $\mathrm{L} 4$ DRG. These same DRG are schematically depicted in camera lucida tracings: $a$, normal; $c$, ligated ( $7 \mathrm{~d})$; and $e$, transected (7 d). In the camera lucida drawings the neurons expressing ${ }^{125} \mathrm{I}-$ PYY receptors are denoted by solid profiles, whereas the nonexpressing neurons are denoted in open profiles. Note that although the neurons that are labeled express very high levels of ${ }^{125}$ IPYY binding sites, neither the density of binding nor the size or percentage of DRG neurons expressing the ${ }^{125}$ I-PYY binding sites appears to be significantly altered after either ligation or transection of the sciatic nerve. Scale bar, 150 $\mu \mathrm{m}$.
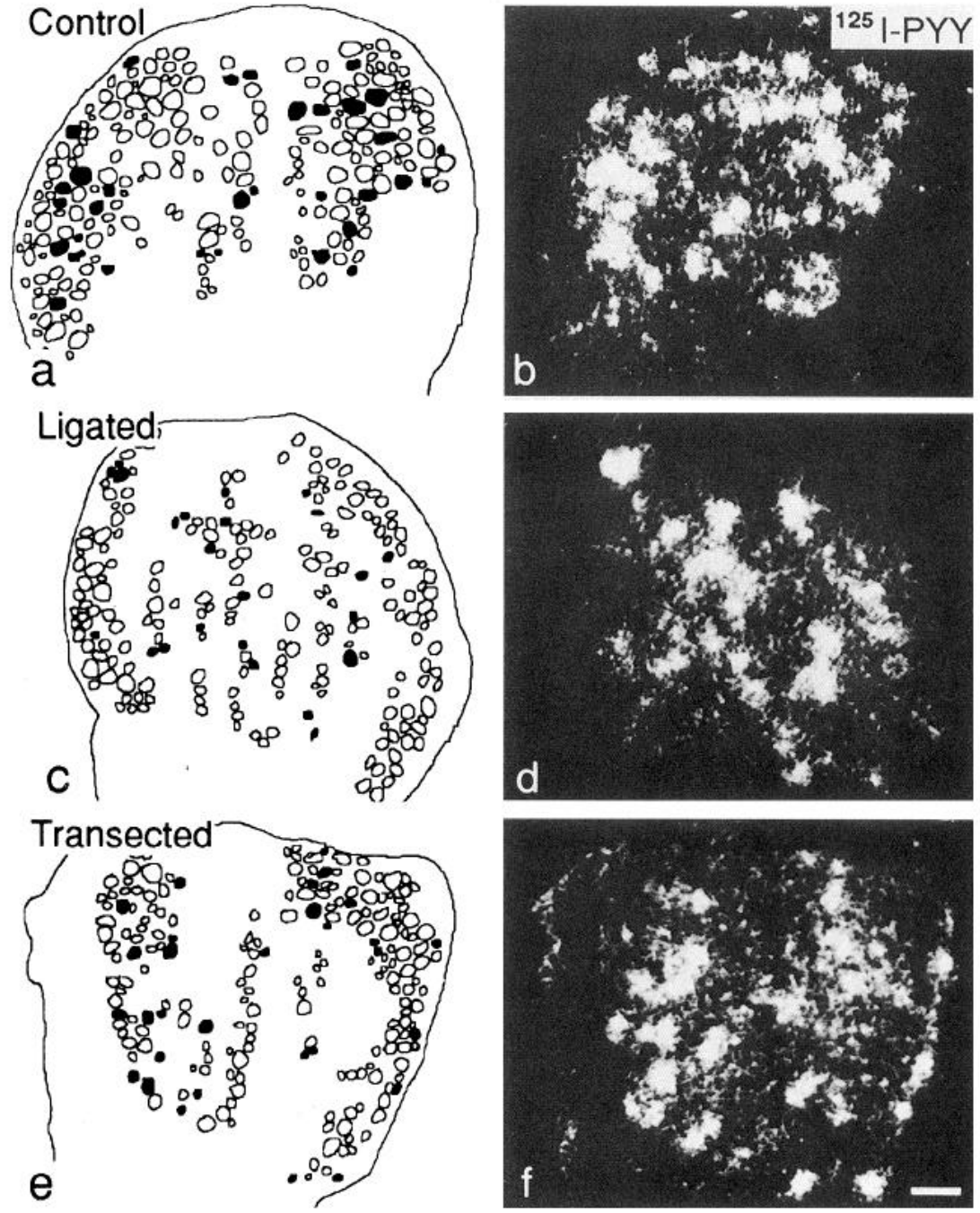

a $10^{-8} \mathrm{M}$ concentration of the $\mathrm{Y} 2$ agonist $\mathrm{NPY}_{13-36}$, nearly all ${ }^{125} \mathrm{I}-\mathrm{PYY}$ binding to rat DRG neurons was displaced, whereas $\mathrm{Leu}^{31}, \mathrm{Pro}^{34}$-NPY at the same concentration showed little displacement of the binding to rat DRG neurons.

\section{Autoradiographic analysis of ${ }^{125} I-P Y Y$ binding sites in the monkey DRG and spinal cord}

Several dozen monkey DRG were examined for ${ }^{125} \mathrm{I}-\mathrm{PYY}$ binding sites. As was found in the rat and rabbit, nearly all the saturable ${ }^{125} \mathrm{I}$-PPY binding sites were observed over neurons with very low levels of ${ }^{125} \mathrm{I}-\mathrm{PYY}$ saturable binding present over the surrounding supporting cells (Fig. 5f). Several thousand monkey DRG neurons were examined for ${ }^{125} \mathrm{I}-\mathrm{PYY}$ labeling at all spinal cord levels. The ${ }^{125} \mathrm{I}-\mathrm{PYY}$ ligand bound saturably to $17.6 \pm 4.7 \%(N=2093), 9.5 \pm 3.2 \%(N=1607), 9.0 \pm 5.9 \%$ $(N=2205)$, and $12.1 \pm 5.0 \%(N=1632)$ of the neurons in the cervical, thoracic, lumbar, and sacral ganglia, respectively.

Although a full displacement curve was not performed on

Table 1. Percentages of DRG neurons expressing ${ }^{125}$ I-PYY receptor binding sites

\begin{tabular}{llll} 
& 7 day & 14 day & 28 day \\
\hline Ligation & & & \\
$\quad$ Contra & $11.43 \pm 1.10(746 / 85)$ & $17.40 \pm 9.68(1341 / 220)$ & $15.08 \pm 1.31(444 / 67)$ \\
$\quad$ Experimental & $11.76 \pm 3.30(774 / 90)$ & $17.88 \pm 8.26(1497 / 271)$ & $10.32 \pm 1.47(690 / 73)$ \\
Transection & & & \\
$\quad$ Contra & $10.05 \pm 1.35(429 / 43)$ & $17.22 \pm 7.07(306 / 50)$ & $17.54 \pm 3.06(1051 / 181)$ \\
Experimental & $15.85 \pm 5.56(333 / 54)$ & $15.09 \pm 4.70(606 / 91)$ & $20.79 \pm 4.71(748 / 153)$
\end{tabular}

The numbers in each column indicate the percentage of DRG neurons expressing ${ }^{125}$ I-PYY binding sites. The animals had either a unilateral ligation or transection of the sciatic nerve and were killed at various time points after the peripheral nerve injury. The numbers in parentheses indicate the total number of DRG neurons counted/number of DRG expressing ${ }^{125}$ I-PYY binding sites. 
monkey spinal cord or DRG, the Y2 agonist NPY ${ }_{13-36}$ at a concentration of $1 \mu \mathrm{M}$ displaced nearly all ${ }^{125}$ I-PYY binding to monkey DRG and spinal cord (Fig. 6), whereas Leu ${ }^{31}$ Pro $^{34}$ NPY at the same concentration caused little displacement of ${ }^{125}$ I-PYY binding to these same tissues.

In the monkey spinal cord, results similar to the rat and rabbit were obtained, with high concentrations of binding sites being observed in laminae I, II, V, and X at all spinal levels, whereas low but detectable concentrations of specific ${ }^{125}$ I-PYY binding sites were observed in laminae III-IX (Figs. 5, 6).

\section{Discussion}

NPY actions on sensory nerve terminals in the spinal cord

Previous studies have shown that there are high concentrations of NPY immunoreactivity in the superficial spinal cord (Gibson et al., 1981; Suburo et al,, 1992), where high concentrations of NPY receptors are also expressed and where small-diameter nociceptive sensory neurons are known to terminate (Willis and Coggeshall, 1991). Intrathecal infusion of NPY in the spinal cord has been shown to inhibit the release of both substance $P$ and calcitonin gene-related peptide (CGRP) from sensory neurons (Giuliani et al., 1989; Duggan et al., 1991). Since substance $\mathrm{P}$ has been reported to be involved in conveying nociceptive information in the spinal cord (De Koninck and Henry, 1991; Salter and Henry, 1991), these results suggest that NPY exerts its reported antinociceptive actions (Hua et al., 1991) by directly inhibiting the release of neurotransmitters from trigeminal and DRG neurons.

It has been suggested recently that after injury (loose ligation, crush, or extraction of a tooth) or axotomy, large-diameter DRG neurons, which probably correspond to low-threshold myelinated mechanoreceptors (Willis and Coggeshall, 1991), express NPY immunoreactivity (Wakisaka et al., 1991, 1992; Itotagawa et al., 1993) and mRNA coding for NPY (Wakisaka et al., 1992). These results suggest that, at least in an injured state, a population of large-diameter sensory neurons may provide the ligand (in a paracrine fashion) to occupy the NPY receptors expressed by a population of the medium- and small-diameter sensory neurons. This possibility would also fit with the observation that peripheral nerve injury triggers the sprouting of myelinated afferents (which may correspond to the large-diameter NPYcontaining DRG neurons) into laminae I and II of the spinal cord, which is the spinal laminae where the small thinly or unmyelinated neurons (which may correspond to the smalldiameter NPY receptor-expressing DRG neurons) terminate (Woolf et al., 1992). However, unlike for the ligand NPY, DRG neurons do not appear to alter significantly their expression of NPY receptors after peripheral nerve cuff-induced neuropathy or transection. This paracrine release of NPY may inhibit the release of sensory peptides, such as substance P and CGRP, which are thought to modulate nociception in the spinal cord (De Koninck and Henry, 1991; Radhakrishnan and Henry, 1991). While the clinical relevance of this paracrine NPY interaction among DRG neurons has not yet been explored, it does suggest both a physiological pathway and a mechanism that may be pharmacologically manipulated to control the pain that often results from peripheral nerve injury or disease (Parry and Withrington, 1984).

\section{NPY actions on sensory nerves outside the spinal cord}

Previous data on other receptors expressed by DRG neurons such as opiate or cholecystokinin receptors have shown that

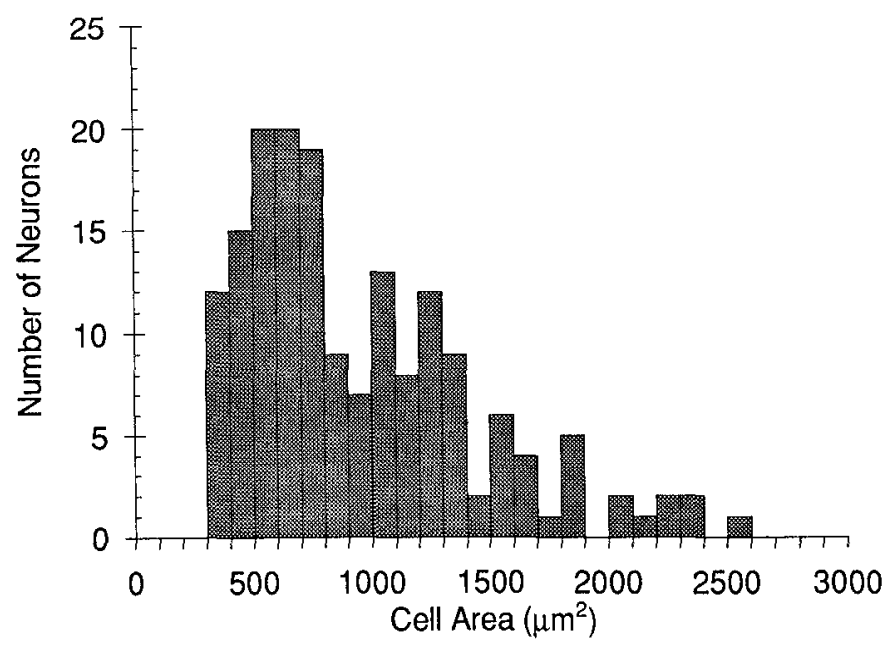

Figure 4. Histogram of the cell body size of rat (L4 and L5) DRG neurons that express NPY receptor binding sites. Note that the majority of DRG neurons that express NY binding sites are small to medium in size.

these receptors are transported within the axon to both the central nerve terminals in the spinal cord and to peripheral nerve terminals in the innervated peripheral tissues (Zarbin et al., 1981, 1990). NPY receptors may be similarly transported to both the central and peripheral terminals. In support of this hypothesis, several reports have demonstrated that peripherally released NPY can modulate neuropeptide release from the peripheral nerve terminals of DRG neurons. In tissues as diverse as the atria, bronchi, ileum, and mesenteric arteries, NPY has been shown to inhibit potently the motor response and the release of substance $P$ and CGRP from the sensory neurons innervating these tissues (Giuliani et al., 1989; Kawasaki et al., 1991; Takaki and Nakayama, 1991). Since substance P release from peripheral terminals of DRG neurons is known to mediate neurogenic inflammation and plasma extravasation (Lam and Ferrell, 1991; Santicioli et al., 1993), peripherally released NPY may prove to be an effective agent in blocking the neurogenic inflammation that follows tissue injury in a peripheral tissue.

The NPY that might interact with the NPY receptors of trigeminal and DRG neurons could arise from several sources. A population of both sympathetic and parasympathetic neurons has been shown to synthesize and release NPY in peripheral tissues (Lundberg et al., 1982, 1990; Franco-Cereceda et al., 1985; Lacroix et al., 1990; Schalling et al., 1991). This interaction of sympathetically and parasympathetically released NPY with sensory nerve terminals may be one of the modes by which sympathetic nerves normally regulate the activities of sensory neurons. Since loss of sympathetic control of sensory neurons is thought to be a contributing factor in the chronic pain state of reflex sympathetic dystrophy (McLachlan et al., 1993), and NPY in sympathetic neurons can inhibit the release of excitatory neurotransmitters by sensory neurons (Giuliani et al., 1989; Duggan et al., 1991; Kawasaki et al., 1991; Takaki and Nakayama, 1991), NPY agonists may prove useful in the treatment of this chronic pain state.

In most cases, sympathetic control of DRG neurons is thought to take place at the peripheral terminals of DRG neurons (Mantyh et al., 1992). In a recent article, however, it was reported that after peripheral nerve injury, sympathetic fibers could be found surrounding the cell bodies of sensory neurons within the 

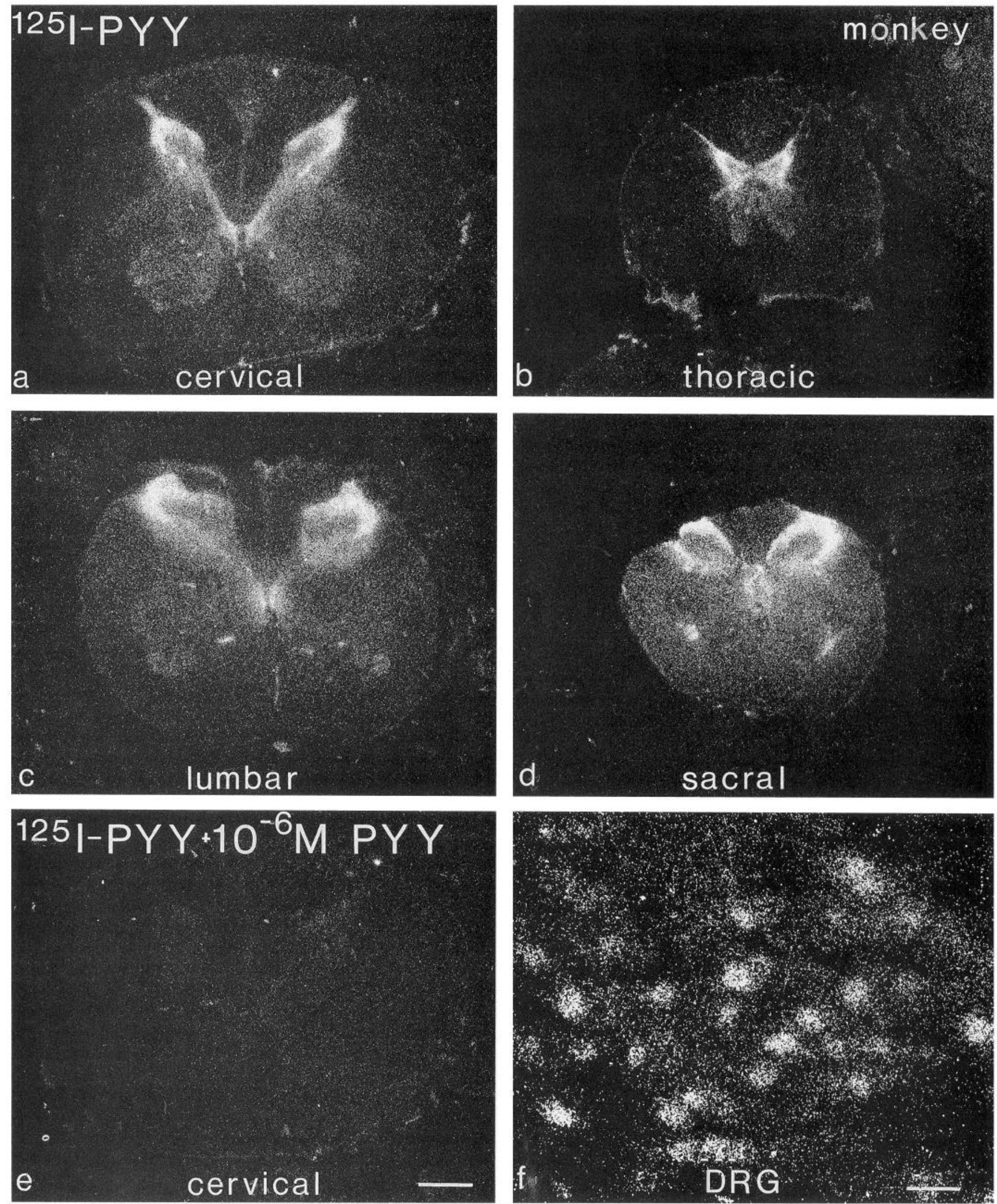

Figure 5. Autoradiographic distribution of ${ }^{125} \mathrm{I}-\mathrm{PYY}$ receptor binding sites in monkey spinal cord and DRG neurons. Dark-field photomicrographs are autoradiograms of monkey cervical $(a)$, thoracic $(b)$, lumbar $(c)$, and sacral $(d)$ spinal cord. Note that in the spinal cord the highest density of binding sites occurs in laminae I, II, V, X, and Onuf's nucleus. The control section shown in $e$ is a section serially adjacent to $a$. Note also the binding to individual monkey cervical DRG neurons in $f$ is similar to that observed in rabbit (Fig. 2). Scale bars: $1.2 \mathrm{~mm}$ for $a-e, 100 \mu \mathrm{m}$ for $f$. 

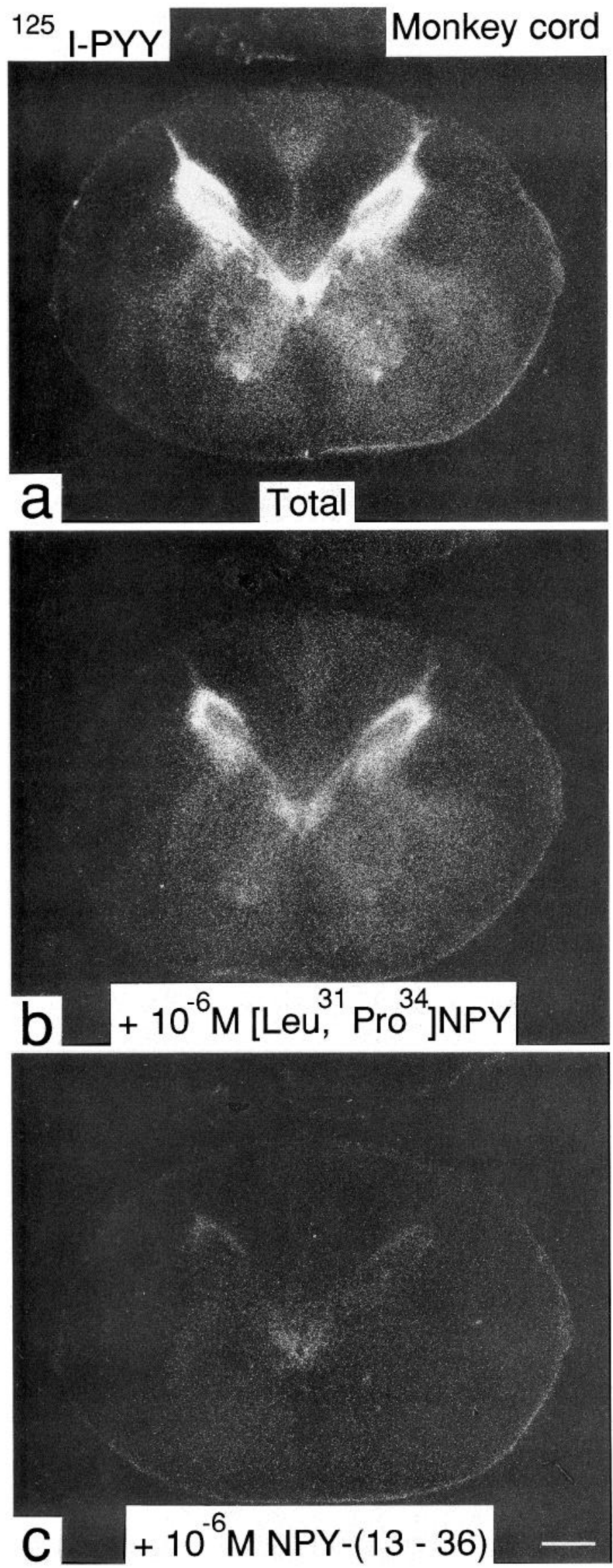

DRG itself (McLachlan et al., 1993). The majority of sympathetic nerves expressing noradrenaline also express NPY (Lundberg et al., 1990). These results suggest that after peripheral nerve injury, sources of NPY that might occupy NPY receptors present on the cell bodies of small- and medium-diameter DRG neurons include not only large-diameter DRG neurons but also sympathetic nerve terminals that are present next to the cell bodies of the sensory neurons within the DRG itself. Although it is generally thought that little or no synaptic activity occurs within the trigeminal ganglia or the DRG itself(Willis and Coggeshall, 1991), the demonstrations that DRG neuron cell bodies express NPY receptors, that after injury DRG neurons can express NPY, and that after injury sympathetic nerves sprout within dorsal root ganglia (McLachlan et al., 1993) suggest that after peripheral nerve injury NPY may act directly on DRG cell bodies expressing NPY receptors.

\section{Percentage of trigeminal ganglia and DRG neurons expressing NPY receptors}

In the present study we observed that a substantial number of trigeminal and DRG neurons express NPY receptors in the rat, rabbit, and monkey. However, we never observed saturable binding sites over more than $20.7 \%$ of the neurons in any trigeminal ganglia or the DRG. In a previous report, however, using electrophysiological recordings from 2-week-old cultures of neonatal rats, NPY inhibited the $\mathrm{Ca}^{2+}$ current in every cell tested (Walker et al., 1988). There are several possible explanations for these apparently discrepant findings.

In the previous study the cells examined were cultured DRG neurons obtained from neonates; in the present experiments we are examining noncultured adult DRG neurons. Previous reports have noted that developing neurons are often more promiscuous in the number of neurotransmitters and receptors they express, compared to older, more differentiated neurons. For example, NPY-like immunoreactivity is transiently expressed in embryonic and fetal human DRG neurons (Suburo et al., 1992) and damaged rodent (Wakisaka et al., 1991) DRG neurons, whereas NPY has not been detected in normal adult DRG neurons (Wakisaka et al., 1991).

A second explanation may be that after 2 weeks in culture, DRG neurons that normally do not express NPY receptors may begin to express the receptors. A similar in vivo and in vitro induction of peptide receptors has been noted for substance $\mathbf{P}$ receptors. Thus, whereas substance $P$ receptors cannot be detected on astrocytes in the normal brain, these same astrocytes express very high levels of substance $P$ receptors after nearby neuronal injury (Mantyh et al., 1989). Similarly, whereas astrocytes express very low levels of substance $P$ receptors immediately after being placed in culture, after $10 \mathrm{~d}$ in culture these same astrocytes dramatically upregulate their expression of substance P receptors (Torrens et al., 1989; Rogers et al., 1993).

\footnotetext{
Figure 6. Localization and characterization of ${ }^{125}$ I-PYY receptor binding sites in the monkey spinal cord. $a$, Dark-field photomicrograph of LKB tritium-sensitive film that has been apposed to a section of the monkey cord that had been incubated with the ${ }^{125}$ I-PYY ligand. $b$ and $c$, ${ }^{125}$ I-PYY binding in a section serially adjacent to $a$ that has been treated identically as $a$ except that in $b 10^{-6} \mathrm{M} \mathrm{Leu}^{31}, \mathrm{Pro}^{34}$-NPY (a Y1 receptor agonist) and in $c 10^{-6} \mathrm{M} \mathrm{NPY}_{(13-36)}$ (a Y2 receptor agonist) has been added to the incubation medium. Note that the majority of binding sites are displaced by the $\mathrm{Y} 2$ agonist and remain in the presence of a similar concentration of the Yl agonist. Scale bar, $0.6 \mathrm{~mm}$.
} 
Third, the electrophysiological techniques employed in the previous study may simply be more sensitive than the autoradiographic methods used to detect the expression of NPY receptors in the present study. We show here that there is substantial variation in the concentration of NPY receptor binding sites over individual trigeminal ganglia and DRG neurons. Thus, whereas some DRG neurons express very high levels of NPY receptors, other DRG neurons have one-fifth of the concentration (Fig. $1 a$ ) and in others the expression of ${ }^{125} \mathrm{I}-\mathrm{PYY}$ binding sites is undetectable. Since we have defined labeled neurons as those neurons having a receptor level greater than fourfold higher than background, DRG neurons that express a lower density than we can detect, but are detectable by electrophysiological techniques, may give rise to the apparent discrepancy in the percent of neurons expressing NPY receptors observed in the two studies.

Lastly, in the previous report the authors did not control for the possibility that NPY perfusion of the cultured DRG neurons might itself promote the release of factors that would effect neighboring cells. Thus, the percentage of cells responding to NPY might have been spurious due to the indirect actions of NPY, rather than a direct NPY receptor-mediated action in every DRG neuron tested.

\section{Response of sensory neurons to NPY receptor activation}

NPY appears to modulate DRG neurons by affecting calcium channels, which in turn inhibit the release of neurotransmitters from sensory neurons. In cultures of neonatal rat DRG, NPY has been shown to inhibit calcium currents via a pertussis toxinsensitive pathway and to inhibit the depolarization-induced release of substance P (Walker et al., 1988). NPY also selectively inhibits the responses produced by the $\omega$-conotoxin-sensitive $\mathrm{Ca}^{2+}$ channel (Thayer and Miller, 1990), suggesting that the inhibition of voltage-sensitive calcium channels is the likely mechanism by which NPY inhibits sensory neurons.

Sensory neurons appear to express receptors for several neurotransmitters in addition to NPY, including adenosine (Taiwo and Levine, 1990), noradrenaline (Holz et al., 1988), bradykinin (Steranka et al., 1988), cholecystokinin (Ghilardi et al., 1992, 1994), GABA (Holz et al., 1988), prostaglandin $E_{2}$ (Taiwo et al., 1987), opioids (Ninkovic and Hunt, 1985), and 5-HT (Taiwo and Levine, 1992). While there is little evidence that these ligands interact at the same receptor, there are substantial data suggesting that different receptors on the same neuron ultimately integrate their actions via G-protein effects on second messenger levels, which in turn effect $\mathrm{Ca}^{2+}$ channels (Thayer and Miller, 1990; Levine et al., 1993). One example of this is the interaction of bradykinin and NPY on DRG neurons. Bradykinin promotes the release of substance $P$ from sensory nerve terminals by activation of a pertussis toxin-insensitive G-protein, which in turn stimulates arachidonic acid release and thus activates a voltagesensitive calcium channel (Thayer et al., 1988; Bleakman et al., 1990). NPY, on the other hand, inhibits the release of substance $P$ from DRG neurons by activation of a pertussis toxin-sensitive G-protein, which in turn inhibits the same voltage-sensitive calcium channels (Ewald et al., 1988; Bleakman et al., 1991). These results together with the present study suggest that a key to understanding the sensitization and facilitation of primary afferents is to understand the repertoire of receptors and their associated second messenger systems expressed and activated in DRG neurons in normal and pathological states. This understanding might provide a rational approach for targeting an- algesic agents that act specifically on the primary afferent neuron itself and thereby avoid many of the deleterious CNS side effects frequently observed with potent analgesic agents.

\section{Summary}

We have demonstrated that a significant population of smalland medium-diameter trigeminal ganglion and DRG neurons express NPY receptors in the rat, rabbit, and monkey. Previous data on other receptors expressed by DRG neurons suggest that NPY receptors synthesized in the cell bodies of trigeminal ganglion and DRG neurons are transported both centrally to the spinal cord and peripherally to the innervated tissue and constitute a target for released NPY at both sites. After peripheral nerve injury, large-diameter DRG neurons express NPY and sympathetic nerve terminals, many of which previously have been shown to contain NPY, appear near the cell bodies of DRG neurons. These data suggest that NPY is uniquely positioned to modulate DRG neurons not only in their central and peripheral terminals, but perhaps also on the DRG neuron cell body.

\section{References}

Allen CJ, Ghilardi JR, Vigna SR, Mannon PJ, Taylor IL, McVey DC, Maggio JE, Mantyh PW (1993) Neuropeptide Y/peptide YY receptor binding sites in the heart: localization and pharmacological characterization. Neuroscience 53:889-898.

Barnes PJ, Belvisi MG, Rogers DF (1990) Modulation of neurogenic inflammation: novel approaches to inflammatory disease. Trends Pharmacol Sci 11:185-189.

Bennett GJ, Xie YK (1988) A peripheral mononeuropathy in rat that produces disorders of pain sensation like those seen in man. Pain 33: 87-107.

Bleakman D, Thayer SA, Glaum SR, Miller RJ (1990) Bradykinininduced modulation of calcium signals in rat dorsal root ganglion neurons in vitro. Mol Pharmacol 38:785-796.

Bleakman D, Colmers WF, Fournier A, Miller RJ (1991) Neuropeptide $\mathrm{Y}$ inhibits $\mathrm{Ca}^{2+}$ influx into cultured dorsal root ganglion neurones of the rat via a $Y_{2}$ receptor. Br J Pharmacol 103:1781-1789.

De Koninck Y, Henry JL (1991) Substance P-mediated slow excitatory postsynaptic potential elicited in dorsal horn neurons in vivo by noxious stimulation. Proc Natl Acad Sci USA 88:11344-11348.

Duggan AW, Hope PJ, Lang CW (1991) Microinjection of neuropeptide $Y$ into the superficial dorsal horn reduces stimulus-evoked release of immunoreactive substance $P$ in the anaesthetized cat. Neuroscience 44:733-740.

Ewald DA, Matthies HJG, Perney TM, Walker MW, Miller RJ (1988) The effect of down regulation of protein kinase $C$ on the inhibitory modulation of dorsal root ganglion neuron $\mathrm{Ca}^{2+}$ currents by neuropeptide Y. J Neurosci 8:2447-2451.

Franco-Cereceda A, Lundberg JM, Dahlof C (1985) Neuropeptide Y and sympathetic control of heart contractility and coronary vascular tone. Acta Physiol Scand 124:361-369.

Fuhlendorff J, Johansen NL, Melberg SG, Thogersen H, Schwartz TW (1990) The antiparallel pancreatic polypeptide fold in the binding of neuropeptide $Y$ to $Y_{1}$ and $Y_{2}$ receptors. J Biol Chem 265:1170611712.

Ghilardi JR, Allen CJ, Vigna SR, McVey DC, Mantyh PW (1992) Trigeminal and dorsal root ganglion neurons express CCK receptor binding sites in the rat, rabbit and monkey: possible site of opiateCCK analgesic interactions. J Neurosci 12:4854-4866.

Ghilardi JR, Allen CJ, Vigna SR, McVey DC, Mantyh PW (1994) Cholecystokinin and neuropeptide $Y$ receptors on single rabbit vagal afferent ganglion neurons: site of prejunctional modulation of visceral sensory neurons. Brain Res, in press.

Gibson SJ, Polak JM, Bloom SR, Wall PD (1981) The distribution of nine peptides in rat spinal cord with special emphasis on the substantia gelatinosa and on the area around the central canal (lamina X). J Comp Neurol 201:65-79

Gimpl G, Gerstberger R, Mauss U, Klotz K-N, Lang RE (1990) Solubilization and characterization of active neuropeptide $Y$ receptors from rabbit kidney. J Biol Chem 265:18142-18147. 
Giuliani S, Maggi CA, Meli A (1989) Prejunctional modulatory action of neuropeptide $Y$ on peripheral terminals of capsaicin-sensitive sensory nerves. Br J Pharmacol 98:407-412.

Holz GG, Kream RM, Dunlap K (1988) Norepinephrine and ganma aminobutyric acid inhibit electrically evoked release of substance $P$ from dorsal root ganglion neurons. J Neurosci 8:463-471.

Hua X-Y, Boublik JH, Spicer MA, Rivier JE, Brown MR, Yaksh TL (1991) The antinociceptive effects of spinally administered neuropeptide $\mathrm{Y}$ in the rat: systematic studies on structure-activity relationship. J Pharmacol Exp Ther 258:243-248.

Itotagawa T, Yamanaka H, Wakisaka S, Sasaki Y, Kato J, Kurisu K, Tsuchitani Y (1993) Appearance of neuropeptide Y-like immunoreactivity in the rat trigeminal ganglion following dental injuries. Arch Oral Biol 38:725-728.

Jorgensen JC, Fuhlendorff J, Schwartz TW (1990) Structure-function studies on neuropeptide $Y$ and pancreatic polypeptide-evidence for two PP-fold receptors in vas deferens. Eur J Pharmacol 186:105-114.

Kandel ER, Schwartz JH, Jessell TM (1991) Principles of neural science. New York: Elsevier.

Kawasaki H, Nuki C, Saito A, Takasaki K (1991) NPY modulates neurotransmission of CGRP-containing vasodilator nerves in rat mesenteric arteries. Am J Physiol 261:H683-H690.

Kruger L, Silverman JD, Mantyh PW, Sternini C, Brecha NC (1989) Peripheral patterns of calcitonin-gene-related peptide general somatic sensory innervation: cutaneous and deep terminations. J Comp Neurol 280:291-302.

Lacroix JS, Änggård A, Hökfelt T, O'Hare MMT, Fahrenkrug J, Lundberg JM (1990) Neuropeptide Y: presence in sympathetic and parasympathetic innervation of the nasal mucosa. Cell Tissue Res 259: 119-128.

Lam FY, Ferrell WR (1991) Specific neurokinin receptors mediate plasma extravasation in the rat knee joint. Br J Pharmacol 103:12631267.

Lei Y-H, Barnes PJ, Rogers DF (1992) Inhibition of neurogenic plasma exudation in guinea-pig airways by CP-96,345, a new non-peptide $\mathrm{NK}_{1}$ receptor antagonist. Br J Pharmacol 105:261-262.

Lembeck F, Holzer $\mathbf{P}$ (1979) Substance $P$ as a neurogenic mediator of antidromic vasodilatation and neurogenic plasma extravasation. Naunyn Schmiedebergs Arch Pharmacol 310:175-183.

Levine JD, Taiwo YO (1989) Involvement of the mu-opiate receptor in peripheral analgesia. Neuroscience 32:571-575.

Levine JD, Fields HL, Basbaum AI (1993) Peptides and the primary afferent nociceptor. J Neurosci 13:2273-2286.

Lötvall JO, Lemen RJ, Hui KP, Barnes PJ, Chung KF (1990) Airflow obstruction after substance $P$ aerosol: contribution of airway and pulmonary edema. J Appl Physiol 69:1473-1478.

Louis SM, Jamieson A, Russell NJW, Dockray GJ (1989) The role of substance $P$ and calcitonin gene-related peptide in neurogenic plasma extravasation and vasodilatation in the rat. Neuroscience 32:581586.

Lundberg JM, Hökfelt T, Änggård A, Terenius L, Elde R, Markey K, Goldstein M, Kimmel J (1982) Organizational principles in the peripheral sympathetic nervous system: subdivision by coexisting peptides (somatostatin-, avian pancreatic polypeptide-, and vasoactive intestinal polypeptide-like immunoreactive materials). Proc Natl Acad Sci USA 79:1303-1307.

Lundberg JM, Franco-Cereceda A, Lacroix J-S, Pernow J (1990) Neuropeptide $Y$ and sympathetic neurotransmission. Ann NY Acad Sci 611:166-174.

Mantyh CR, Gates TS, Zimmerman RP, Welton ML, Passaro EP Jr, Vigna SR, Maggio JE, Kruger L, Mantyh PW (1988) Receptor binding sites for substance $P$, but not substance $K$ or neuromedin $K$, are expressed in high concentrations by arterioles, venules, and lymph nodules in surgical specimens obtained from patients with ulcerative colitis and Crohn disease. Proc Natl Acad Sci USA 85:3235-3239.

Mantyh PW, Johnson DJ, Boehmer CG, Catton MD, Vinters HV, Maggio JE, Too HP, Vigna SR (1989) Substance $P$ receptor binding sites are expressed by glia in vivo after neuronal injury. Proc Natl Acad Sci USA 86:5193-5197.

Mantyh PW, Catton MD, Allen CJ, Labenski ME, Maggio JE, Vigna SR (1992) Receptor binding sites for cholecystokinin, galanin, somatostatin, substance $P$ and vasoactive intestinal polypeptide in sympathetic ganglia. Neuroscience 46:739-754.

McLachlan EM, Jänig W, Devor M, Michaclis M (1993) Pcriphcral nerve injury triggers noradrenergic sprouting within dorsal root ganglia. Nature 363:543-546.
Mosconi T, Kruger L (1992) Electron microscopic analysis of axon fiber spectrum following neuropathy hyperpathia produced by fixeddiameter nerve constriction. Soc Neurosci Abstr 18:289.

Ninkovic M, Hunt SP (1985) Opiate and histamine Hl receptors are present on some substance $\mathrm{P}$-containing dorsal root ganglion cells Neurosci Lett 53:133-137.

Noguchi K, De Leön M, Nahin RL, Senba E, Ruda MA (1993) Quantification of axotomy-induced alteration of neuropeptide mRNAs in dorsal root ganglion neurons with special reference to neuropeptide Y mRNA and the effects of neonatal capsaicin treatment. J Neurosci Res 35:54-66.

Parry CBW, Withrington R (1984) The management of painful peripheral nerve disorders. In: Textbook of pain (Wall PD, Melzack R, eds), pp 395-401. Edinburgh: Churchill Livingstone.

Pedersen-Bjergaard U, Nielsen LB, Jensen K, Edvinsson L, Jansen I, Olesen J (1991) Calcitonin gene-related peptide, neurokinin A and substance $P$ : effects on nociception and neurogenic inflammation in human skin and temporal musclc. Peptides 12:333-337.

Radhakrishnan V, Henry JL (1991) Novel substance P antagonist, CP-96,345, blocks responses of cat spinal dorsal horn neurons to noxious cutaneous stimulation and to substance P. Neurosci Lett 132 : $39-43$.

Rogers SD, Allen CJ, Ghilardi JR, Stimson ER, Vigna SR, Maggio JE, Mantyh PW (1993) In vivo time course of NK-1 receptor expression in astrocytes after neuronal injury. Soc Neurosci Abstr 19.

Salter MW, Henry JL (1991) Responses of functionally identified neurones in the dorsal horn of the cat spinal cord to substance $\mathrm{P}$, neurokinin A and physalaemin. Neuroscience 43:601-610.

Santicioli P, Giuliani S, Maggi CA (1993) Failure of L-nitroarginine, a nitric oxide synthase inhibitor, to affect hypotension and plasma protein extravasation produced by tachykinin NK-1 receptor activation in rats. J Auton Pharmacol 13:193-199.

Schalling M, Franco-Cereceda A, Hemsén A, Dagerlind $\AA$, Seroogy K, Persson H, Hökfelt T, Lundberg JM (1991) Neuropeptide Y and catecholamine synthesizing enzymes and their mRNAs in rat sympathetic neurons and adrenal glands: studies on expression, synthesis and axonal transport after pharmacological and experimental manipulations using hybridization techniques and radioimmunoassay. Neuroscience 41:753-766.

Sheikh SP, O’Hare MMT, Tortora O, Schwartz TW (1989) Binding of monoiodinated neuropeptide $\mathrm{Y}$ to hippocampal membranes and human neuroblastoma cell lines. J Biol Chem 264:6648-6654.

Stein C, Gramsch C, Herz A (1990a) Intrinsic mechanisms of antinociception in inflammation: local opioid receptors and $\beta$-endorphin. J Neurosci 10:1292-1298.

Stein C, Hassan AHS, Przewlocki R, Gramsch C, Peter K, Herz A (1990b) Opioids from immunocytes interact with receptors on sensory nerves to inhibit nociception in inflammation. Proc Natl Acad Sci USA 87:5935-5939.

Steranka LR, Manning DC, DeHaas CJ, Ferkany JW, Borosky SA, Connor JR, Vavrek RJ, Stewart JM, Snyder SH (1988) Bradykinin as a pain mediator: receptors are localized to sensory neurons, and antagonists have analgesic actions. Proc Natl Acad Sci USA 85:32453249

Suburo AM, Gibson SJ, Moscoso G, Terenghi G, Polak JM (1992) Transient expression of neuropeptide $\mathrm{Y}$ and its $\mathrm{C}$-flanking peptide immunoreactivities in the spinal cord and ganglia of human embryos and fetuses. Neuroscience 46:571-584.

Taiwo YO, Levine JD (1990) Direct cutaneous hyperalgesia induced by adenosine. Neuroscience 38:757-762.

Taiwo YO, Levine JD (1992) Serotonin is a directly-acting hyperalgesic agent in the rat. Neuroscience 48:485-490.

Taiwo YO, Goetzl EJ, Levine JD (1987) Hyperalgesia onset latency suggests a hierarchy of action. Brain Res 423:333-337.

Takaki M, Nakayama S (1991) Prejunctional modulatory action of neuropeptide $\mathrm{Y}$ on responses due to antidromic activation of peripheral terminals of capsaicin-sensitive sensory nerves in the isolated guinea-pig ileum. Br J Pharmacol 103:1449-1452.

Thayer SA, Miller RJ (1990) Regulation of the intracellular free calcium concentration in single rat dorsal root ganglion neurones in vitro. J Physiol (Lond) 425:85-115.

Thayer SA, Perney TM, Miller RJ (1988) Regulation of calcium homcostasis in scnsory ncurons by bradykinin. J Neurosci 8:4089-4097.

Torrens Y, Daguet de Montety MC, el Etr M, Beaujouan JC, Glowinski J (1989) Tachykinin receptors of the NK1 type (substance P) coupled 
positivcly to phospholipase $\mathrm{C}$ on cortical astrocytes from the newborn mouse in primary culture. J Neurochem 52:1913-1918.

Wakisaka S, Kajander KC, Bennett GJ (1991) Increased neuropeptide Y (NPY)-like immunoreactivity in rat sensory neurons following peripheral axotomy. Neurosci Lett 124:200-203.

Wakisaka S, Kajander KC, Bennett GJ (1992) Effects of peripheral nerve injuries and tissue inflammation on the levels of neuropeptide $\mathrm{Y}$-like immunoreactivity in rat primary afferent neurons. Brain Res 598:349-352.

Walker MW, Ewald DA, Perney TM, Miller RJ (1988) Neuropeptide $\mathrm{Y}$ modulates neurotransmitter release and $\mathrm{Ca}^{++}$currents in rat sensory neurons. J Neurosei 8:2438-2446.
Willis WD Jr, Coggeshall RE (1991) Sensory mechanisms of the spinal cord. New York: Plenum.

Woolf CJ, Shortland P, Coggeshall RE (1992) Peripheral nerve injury triggers central sprouting of myelinated afferents. Nature 355:75-78. Zarbin MA, Wamsley JK, Innis RB, Kuhar MJ (1981) Cholecystokinin receptors: presence and axonal flow in the rat vagus nerve. Life Sci 29:697-705.

Zarbin MA, Wamsley JK, Kuhar MJ (1990) Anterograde transport of opioid receptors in rat vagus nerves and dorsal roots of spinal nerves: pharmacology and sensitivity to sodium and guanine nucleotides. Exp Brain Res 81:267-278. 